\title{
Exploring the Researcher's Motivations for University Governance Some Configurations in the African Context
}

\author{
André TIOUMAGNENG \\ Correspondence: Professor in Management Science, Faculty of Economic Sciences and Management, University of \\ Yaounde 2, Head of Research and Development Division, Republic of Cameroon.
}

Received: March 10, 2019

doi:10.11114/bms.v5i3.4482
Accepted: August 15, 2019

Online Published: August 27, 2019

URL: https://doi.org/10.11114/bms.v5i3.4482

\begin{abstract}
The University governance is constantly in crisis in many developing countries especially in Africa. This article is built around the idea that this question cannot be addressed without a prior reflection on the personal expectations that determine the researchers' commitment in their work. Our objective is to contribute to better understanding the researchers' motivations when they decide to publish articles, to write or supervise theses. The study considers the field of Management Sciences where the conceptual debate concerning the value of research rarely mentions what the researcher earn for himself. Data were collected through comprehensive interviews with 55 researchers of two Cameroonian Universities. The analysis puts forth five configurations of motivations that are likely to inspire the deepen reflections on local Universities governance reform.
\end{abstract}

Keywords: university governance, personnel expectations, researcher, management sciences

Universities have long been struggling with different pressures both of internal (explosion of student numbers, working conditions of teachers, etc.) and external (linked to the dynamism of their environment) origins all over the world. The evocation of external pressures gives the opportunity to put forth the combination of different effects. It's about notably of internationalization or globalization, the competition between Universities notably with the increasing number of private Universities. It's about otherwise of the digitalization, the budgetary constraints of States and the instauration in the "New Public Management" perspective of management modes so far implemented in private enterprises (Khefacha $\&$ Belkacem, 2010). Beyond this, Universities find themselves torn between various rationalities among which the vital need for autonomy and the administrative control exercised by the Country's State in which they are located (Enders \& Muselin, 2008).

If there is an area of the University which is strongly affected by most of the constraints over the years, it's it core business. It's about precisely the Research which is a knowledge-producing activity that many authors consider as the poorly governed and often overlooked component in many developing countries Universities (Houcine, 2017; Damtew \& Heinz, 2010).Thus, this knowledge is constantly called not to be only scholarly knowledge, in the sense of the positivist paradigm that values the abstract, but actionable or pragmatic knowledge that can be used to transform the society and firms (Barthélemy, 2012).

This double challenge is not without consequences on Universities' governance especially in Africa (Gaillard and Gaast, 1988). We consider, in this work, the governance as the policy and decision-making elaboration process at the macro level in the University or in higher education in general (Kezar \& Heckel, 2004). It particularly affects wage policies, incentives, professional career and more generally Human Resources Management in the University (Gatignol, 2014, Gordon \& Whitchurch, 2007). "Good governance" also means ethical University steering or regulation modes that take into account the motivation of stakeholders in general and researchers especially (Houcine, 2017).

It is common to consider that each University pursue a three-dimensional mission involving research, teaching and support to development which refers to applied research (Jazziri \& Levy-Tadjine, 2009) ${ }^{1}$.This article is in line with studies on the first dimension. We are interested in the practitioners of the research activity, commonly called "researchers", especially those in the field of Management Sciences that we shall call Managers in this work.

\footnotetext{
${ }^{1}$ Nevertheless, we are witnessing in recent years the proliferation of missions devolved to Universities. Jazziri \& Levy-Tajin (2009) provide a summary of the new missions.
} 
The Management sciences is a recent field in which investigations devoted to the researcher's work, both from an epistemic angle and from the University governance point of view, have multiplied over the past decade (Courpasson \& Guedri, 2007; Glick, Miller \& Cardinal, 2007; Benis \& O'Toole, 2005) ${ }^{2}$. These reforms, which vary in size and degree depending on the country and the University, have particularly evolved since the 1980s and 1990s. These are continuing in Universities in the United States of America, Canada, Europe and Africa. In Africa notably, we can mention as illustration the University reforms made in Tunisia in 2016, Algeria in 2005, Ivory Coast between 1991 and 1998 and in Cameroon in 1993. In countries such as France, change results from demands expressed by the researchers themselves who particularly claim the recognition of their status in the University research system (Girolamo, 2004).

Our study focuses on Cameroun and concerns two local Universities; the University of Yaounde II (UYII) and the University of Douala (UD) which are all more than 25 years. Indeed, these Universities has been created within the frame of 1993 University reform. This reform has introduced a quarterly premium for the modernization of research in order, amongst others objectives, to improve the living and working conditions of the researchers (Menye, 2014). The main reason behind our work is that, in Cameroon as well as in other African countries notably, the new configurations of University governance resulting from change processes prove to be sub-optimal and productive of crises that are urging for new reforms (Makosso \& al., 2009).

The "burn-out" identified in many research laboratories, especially in Western Universities, is an excellent illustration of such crises. The resulting psychosocial risks (stress, suicide, etc.) of researchers arise from personal fulfillment difficulties they experience. The new rules instilled by reforms also contribute to the undermining of researchers psychology leading these to their nomadism, exodus abroad and the strike (Menye, 2014) like the one (often described as "historical") that took place in France in 2004.

The idea is that the transformations of Universities exhibit researchers to strong tensions in their personal ethics. These tensions define and complicate the strategies they develop for their professional success. They concern different points (search for private financing, academic and administrative promotion, scientific publication, etc.) on which there is a myriad of works(Gatignol, 2014; Louvel \& Valette, 2014).These authors notably show the interest of understanding such tensions for the elaboration of university good governance

Nevertheless if the studies of researchers' satisfaction conditions appear as a strategic challenge for relevant University governance, it's clear that there is little researches studying this matter when it comes to Universities in Africa. Our article attempts to fill thes gap. It apprehends the researcher-Manager in the light of Personalist or Kantian philosophy, psychology and humanist ideology which invite to consider him as animated by personal values or desires. Some authors show that these desires are defensible in the execution of research activities (Paradas, 2012). The epistemological problem raised by such a view is that of the selfish or self-referential character of any research (whether Manager or not) which, as we will see later in this work, is far from being marginal for University governance (Louvel \& Valette, 2014; Courpasson \& Guedri, 2007).

In light of the above, the purpose of this article is to contribute to better understanding the motivations or desires $^{3}$ determining the involvement of the researcher in his work. The study is centered on the in Management Sciences domain and organized around three sections or parts. First of all, it is a conceptual exploration that will consist to discuss with reference to Karl Polanyi's philosophy of knowledge, the problem of dehumanization of the scientific act (Baumard, 2012) in the first part. From our point of view, this dehumanization appears as a sign of the conception of research activity at the University whose governance finally tends to despise the personal desires of the researcher. Secondly it is an empirical exploration which, in the second part, proceeds from the mobilization of data on Managers ${ }^{4}$ of the two Cameroonian Universities to determine their values. The last section is devoted to the results of the empirical study that organize the researchers concerned into five configurations reflecting their motivations.

\section{The Dehumanization: The Problem of University Research}

University governance crises, especially those related to research, result from different factors. In this paper, we wish to have more of an epistemological view leading to the localization of their origin in a kind of problem representation (by the designers of this governance) of the research that relates to its "dehumanization" (Baumard, 2012).This dehumanization refers in a certain way to the depersonalization of research (Paradas, 2012). It leads to the implicit rejection of the researcher's status as an anthropological being with his own desires whose satisfaction can be targeted in his profession (Alvarez \& Oriot, 2007). It is of course open to criticism as long as one considers that research is never

\footnotetext{
2 Cf.Barthélemy (2012) for a summary.

3 We consider in this work that the notions of motivation, desires and values are synonymous.

4 The concept of Manager is used here to qualify the researcher operating in management sciences.
} 
impersonal (Le Goff, 2012). Especially, the dehumanization appears mostly dangerous for reflections on University governance where the aspects related to the researcher's "ethos" ${ }^{15}$ can be reveal despised.

If there is an area of scientific research where the raised problem of depersonalization has strongly fueled debates during the last two decades, it is that of the Management Sciences which is a discipline whose institutionalization in Universities is however of most recent ${ }^{6}$. According to some authors (Barthélemy, 2012; Verstraete, 2007), it was towards the end of the 1960s and the beginning of the 1970s that the researches in this domain have developed respectively in American and French Universities. In Africa, this development took place a bit late around the 1990s.

We especially wish to note that the utility or the valorization of research is at the center of Management Sciences project and that we especially assist, during the 1980 decade, to the recurrence of debates on this utility. These debates have been interesting over time for the reform of academic governance in research (Courpasson \& Guedri 2007, Benis \& O'Toole 2005). It is most interesting to note that they provide an excellent framework for the verification of the above-mentioned question of dehumanization of research.

Indeed with the growing concern of knowing what is a useful research, authors tend to consider that it is a research that can be used by the firms to solve their management problems (Banks \& al., 2016). It therefore appears that the researcher himself is generally excluded from the list of potential beneficiaries of the results of his work. This situation amounts to unfairly denying the personal nature of any research. Then, it seems problematic ${ }^{7}$.

According to Beyer \& Trist (1982), results that social sciences generally obtain potentially have three forms of utilities: instrumental, conceptual, and symbolic (Beyer \& Trist, 1982).Instrumental utility refers to the congruence of knowledge produced in relation to organizational problems encountered by business leaders (therefore this knowledge must be directly usable by managers). The conceptual utility type refers to the aptitude of this knowledge to serve the interpretation and decoding of the environment or complex phenomena. The third form, the symbolic utility, is conceived with regard to the possibility of exploiting the results of research for the attainment of social legitimacy or power. In this case, research must help to legitimate "good" practices or to discourage the "bad" practiced by the firms (Barthélemy, 2012).

It could be that this triptych (instrumental, conceptual and symbolic utility) concerns the researcher who can be also consider as a practitioner of the research activity. According to Demil, Lecoq \& Warnier (2014), the researcher definitely feels a need to improve his understanding of his environment or studied phenomena. He has also instrumental problems (such as the search for private or public financing and the need for professional integration) and symbolic problems (like the search for social reputation).

Various research studies have recently been developed around the career of researchers' at the University, including junior researchers who are $\mathrm{PhD}$ students. They contribute to legitimizing and understanding the personal problems they face (Doucoure, 2014; Gatignol, 2014; Louvel \& Valette, 2014; Glick \& al., 2007; Verstraete, 2007).

Nevertheless there is an intriguing observation when we thoroughly scrutinize the academic debate on the utility or the value of the research in Management Science. It's about the rhetorical hegemony which considers this utility with respect only to the firms. While it is clear that research is not "out of the world" and should therefore contribute to the transformation of the society constituted notably by the firms, this situation gives unfortunately the false impression that the research is impersonal (Le Goff, 2012). Studies analyzing the interest of research to the researcher point of view (as an actor) prove therefore to be scarce. One of the reasons is that the theme of the utility of research mostly developed in positivist epistemology (Verstraete, 2007) which (according to the sacrosanct principle of objectivity) is opposed to any consideration of desires specific to the researcher.

In the face of the persistent challenge to ensure the utility of research to the firms, some authors suggest that the protocol should be based on (co-) constructivist approaches (Charreire \& Huault, 2001). These approaches are characterized by the consideration they pay to the emotions and desires of the researcher. As the motor of reason according to Antonio Damasio, the emotions of the researcher contribute to the orientation of his choices (Alvarez \& Orot, 2007).

5 "The ethos" represents, in the philosophy of Aristote, the first aspect of ethics and refers to the fantasies and desires of each individual. In this sense it is different from the "ethos" (second slope) which refers to social morality, that is to say, to what is socially forbidden or commonly accepted in the environment in which the individual finds himself.

${ }^{6}$ In relation to certain fields such as Economics, Law or Sociology for example.

${ }^{7}$ This problem notably arises from the fact that, beyond the managerial valuation which takes into account the contribution of research with respect to companies' problems, two other forms of valorizations are omitted: the scientific and academic valuations. 
Many studies mobilize this idea to explain that the manager potentially develops an individual strategy characterized notably by career projections, ambitions of administrative promotion, desires for financial gain or prestige (Enders \& Muselin, 2008; Courpasson \& Guedri, 2007).They help to legitimate the theory that research has an emotional or egocentric character. This theory suggest that we must (re) integrate "the researcher into his research", taking into account his personal or intrinsic values, when exploring the impact or the usefulness of this research. The idea is that research is neither impersonal nor "out-of-the-world"(Le Goff, 2012).

Nevertheless the classical reflections on the utility of research tend to deconstruct the interest of studying the personal satisfaction of the researcher as suggested by this theory. Indeed, it is generally considered that the analysis of what the researcher gains or targets for himself in his research is likely to encourage him to adopt a self-referential approach that limits the relevance of the research from the social or the firm's point of view (Demil, Lecoq \& Warnier, 2014). This article belongs to the perspective that rather values such an analysis. The main idea is that so long as the researcher is considered as a stakeholder in the University system, the study of his personal expectations is likely to contribute to the enrichment of the University governance modeling (Jaziri \& Levy-Tajine, 2009).

This work is mainly based on psychologists' work which lead to doubts about the alleged antagonistic relationship between selfishness (the pursuit of personal ends) and altruism (the willingness to be useful to society) of the researcher. Concerned authors suggest that a way to ensure the predisposition of the researcher to produce knowledge that is useful to the society (his altruism or his pro-social behavior) lies in the quest for his personal happiness (Deschamps \& Finkelstein, 2012).

According to these authors, the action of each individual is defined by his personal values which are perceived as one's desirable ends. They express motivations to achieve specific goals such as safety, success, power, benevolence, accomplishment and autonomy. This statement gives the opportunity to point out that in this study, the concepts of personal desires and personal values are used indifferently as they are considered synonymous.

For recent years, we have been facing the resurgence of different studies based on the individualist paradigm, the personalist theory and the humanist ideology for most of them. These studies militate in favor of more consideration for personal values in the field of Research in Management Sciences, considering that the researcher is a person of interest who prefers what is useful to him (Paradas 2012, Alvarez \& Orot 2007).

As already suggested above, it seems that the so open personalization perspective of research in Management is important. This is of great interest for the organization or the University governance on research as long as we imagine that it rehabilitates the problem of the personal desires of the researcher who can be perceived as an actor (Louvel \& Valette, 2014, Courpasson \& Guedri, 2007).

One can assume that the recognition of the researcher status as a stakeholder of the University (Jazziri \& Levy-Tajin, 2009) helps to justify the challenge of analyzing his personal desires. For the sake of good governance, it is interesting to note that an idea of the stakeholder theory wants the University to be attentive to the aspirations and be concerned with the satisfaction of each of them (Côme, 2013).

Nevertheless academic works in the field of University governance which empirically question the desires or specific aspirations of the researcher are not many, especially in the African context. This work is based on a major idea. It's considered that it can be difficult to effectively address the problematic of poor University governance about the research if we do not allow a reflection on personal motivations of local researchers when they engage in their profession. This statement contributes to raising the importance of deepening the empirical study currently carried out in the Cameroonian context on the individual connection of the researcher to his work and more precisely the desires underlying his commitment.

\section{Empirical Study of the Manager's Motivations}

We sought in this level to understand the personal desires prompting researchers in the field of Management Sciences to notably publish an article, write a book and design or direct doctoral thesis. Good governance would involve listening to researchers, understanding and considering these desires in the development of University policy. This section presents the adopted epistemological positioning and clarifies the methodological approach we have used.

In the field of psychology, personal desires or motivations fundamentally constitute intrapsychic entities whose measurement is logically complex and requires sophisticated techniques such as the Rokeach Value Survey and the List of Value (Deschamps \& Finkelstein, 2012). In others words, the personal motivations are the "mental constructs" existing in the minds of the target actors. From this observation, constructivism has been revealed as the appropriate reference framework to our study. Thus in order to reach the targeted reality that can be associated with "second-grade reality" in Watzlavick's sense, we had to consider the intelligence of the researchers.

Nevertheless the study protocol relies on a pre-existing theoretical framework such as the research on researchers 
'career in the University (Louvel \& Valette, 2014; Makosso \& al., 2009, etc.). The survey is carried out in Cameroon. It is a Central African State usually considered in many intercultural studies as «Africa in miniature». The idea is that it is the crucible of different values among which those of researchers, which concern us. Beyond this, the national ambitions of economic emergence and the contribution of Universities or academics through relevant scientific productions in Africa $^{8}$ give a special interest to this subject.

The study concerns researchers of two public Universities, namely the U.Y.II and the U.D. These Universities were created within the frame of the great higher education reform of the 1990s. This reform consecrated the existence of six public Universities in Cameroon through the decree $\mathrm{N}^{\circ} 92 / 74$ of the $13^{\text {th }}$ of April 1993. However, the Public Universities sector in Cameroon currently counts eight Universities. The most recent ones were created in 2008 and 2011 respectively. Their administrative and academic organization is defined by the decree $\mathrm{N}^{\circ} 99 / 026$ of the $19^{\text {th }}$ of January 1993.

According to this decree, the University teaching body is organized in four grades namely the Full Professors (Pr), the Associate Professors, the Lecturers and Assistant Lecturers. The survey takes into account this structuring while considering that the personal values can vary depending on the academic rank of the researcher (Menye, 2014).For a fine and in-depth analysis of the problem, the study was extended to two other categories of junior researchers namely $\mathrm{PhD}$ holders and doctoral students not currently possessing the status of a University teacher despite their paid activities in support of both administrative and academic ${ }^{9}$ issues. In the context of this study, it is interesting to note that the rank of Assistant Lecturers is the very first rank that one acquires after the University recruitment. Therefore, the junior researchers concerned may $\mathrm{PhD}$ holder or not.

The choice of the University of UYII and the UD is justified by the fact that they are the main centers for research in Management Sciences in Cameroon or in Central Africa given the number of specialized junior and senior researchers they have. These Universities have on average two Full Professors and seven Associate Professors of the AMCHE ${ }^{10}$ in Management beyond the many Assistant Lecturers and Lecturers. These statistics do not take into account the researchers (Lecturers and Associate Professors in this case) promoted through the Consultative Committee of University Institutions (CCIU) which (as an internal system for evaluation and promotion of researchers) still coexists in Cameroon with the AMCHE system.

Data collection is realized through interviews conducted between November 2016 and January 2018 with 55 researchers in Management sciences. We have mobilized the method of interviews. This article is globally explanatory kind taking into account notably the weakness of units of analysis and the qualitative character of the study's method.

The interviews were conducted between November 2016 and January 2018 with 55 researchers made up of doctoral-instructors, Assistants with or without PhD, Lecturers, Associate Professors and Full Professors. Meetings with all the interviewees are unplanned. They are further eased by the fact that author of the article who is, at the same time, the investigator and the target population, is a member of staff in one of the two studied Faculties of Economics and Management Sciences.

Interviews are in general informal and unstructured. They are inspired by the sociological conception of survey of Kauffman (1999). It's about precisely the comprehensive interviews (Kauffman, 1999). The covered topics concern different aspects of the University policy such as salary, research allowance, professional career, teaching, research laboratories and working conditions. Exchanges also mainly focus on the utility of the research activity as it emerges from the work of Banks et al. (2016), Demil, Lecoq \& Warnier (2014) and Barthelemy (2012).

All the interviewees are not aware, when we start the exchange, that they are taking part in the realization of a scientific research project. But in $99 \%$ of cases the interviewer has mentioned, at the end of the exchange, that he is working since some times on a scientific article centered on the problematic of the research value.

We had the main objective when we decide, at the starting of exchange, to not inform the interviewees that they are taking part in the realization of a scientific research project. This objective was to "create collusion", a recreation and a

\footnotetext{
${ }^{8}$ In recent years, most countries in Africa (Ivory Coast, Gabon, Cameroon, etc.) have set the goal of being emerging with different time horizons. The one of Cameroon is 2035.

9 Also called instructors, ATER, etc., these junior researchers are recruited by the Faculty to carry out tutorials to students of lower level and for some logistical and administrative tasks.

${ }^{10}$ African and Malagasy Council of Higher Education
} 
relaxed climate where the interlocutors "chat" or express themselves freely in "conversations" following the requirements of the comprehensive interview (Kauffman, 1999).

The interviews are personal and last 20 minutes averagely. They take place in the cities of Yaoundé and Douala where the UYII and UD are located respectively. Exchanges are spontaneously engaged during the various scientific or academic meetings involving the author-interviewer. These meetings include Faculty boards, general assembly of teachers, $\mathrm{PhD}$ defenses and conferences among others.

The conversational or non-directive nature of interviews implies that they are not based on interview guides. However, an effort is made to adapt the speech on addressed topics to the status or rank of the target researcher (simple $\mathrm{PhD}$ holder / PhD holder and assistant Lecturer for instance).The information from each interview is manually synthesized by the interviewer once separated from the respondents. Finally, it is processed manually through the content analysis. In other words, the answers are codified according to the profiles of researchers (University of origin, grade, etc.) and groupings are carried out for a synthetic vision of the representations.

Table 1. Statistics of respondents by rank, status, gender and by University

\begin{tabular}{l|l|l|l|l}
\hline \multirow{2}{*}{ Status/Rank } & \multicolumn{2}{|c|}{ UYII } & \multicolumn{2}{c}{ UD } \\
\cline { 2 - 5 } & Distribution per gender & Distribution per gender \\
\cline { 2 - 5 } & male & female & male & female \\
\hline Instructor/PhD student & 02 & 04 & 02 & 02 \\
\hline Instructor/PhD holder & 02 & 02 & 01 & 0 \\
\hline Assistant Lecturer (A.L) & 04 & 03 & 03 & 01 \\
\hline Lecturer & 05 & 05 & 03 & 03 \\
\hline Associate Professor (A.P) & 06 & 02 & 04 & 02 \\
\hline Full Professeur (Pr) & 03 & 0 & 0 & 0 \\
\hline
\end{tabular}

Source: data

\section{Discussion of Results}

The outcomes of the analysis highlight that the respondents' representations of the personal utility of their research work appeared not only extremely diverse but dependent of the rank, status, gender and even the University of Origin. Given their complexity and following previous studies on related topics (Louvel \& Vallette, 2014, Courpasson \& Guedri, 2007), the configuration approach appeared appropriate for the organization of results' presentation.

In general, this approach consists in bringing out from the concrete realities diversity, the dominant forms of responses to a problem (Denis et al., 2011).A configuration is an ideal-type or orientation map that contributes to the intelligibility of a problem (Denis \& al., 2011, p.107). In this study, five configurations of researchers are identified. They reflect the orientation of the personal values of investigated researchers towards the appointment in administrative functions ("administrativists"), the professional insertion ("job seekers"), the reputation ("pro-credibility"), the financial gain ("capitalist" configuration) and academic advancement ("académists").

It is very interesting to observe that, in this study, the problems that companies experience are rarely mentioned by our interlocutors when they speak of the usefulness of research activities. However we will not insist too much on this observation, which is all the more surprising because they belong to a scientific domain (management sciences) whose firm constitutes the central object of the study.

\section{1 «Administrativists» Configuration}

If there is a segment of researchers where the desire of promotion in administrative positions has been prominent, it is indeed that of researchers of the highest rank. This expectation mainly characterizes researchers of the U.Y.II (about 85\%, against $55 \%$ for U.D. researchers). This may be partly justified by the proximity of this University to governmental bodies of political decision. This characterizes $90 \%$ of Associate Professors and $10 \%$ of Full Professors.

While appointments are perceived by most AP as a means for financial enrichment, for many Full Professors, it is a sign of social recognition or an opportunity to have offices. Hence we are in a context in which research is essentially instrumental. In fact, we observed here that the research activity, through the change of rank, serves in particular for the promotion to administrative positions both at the University and others public administrations. This result gives the opportunity to observe that the execution of administrative tasks is potentially a vector of legitimacy and power contrary to a widespread idea suggesting that academics perceive it as a waste of time (Dahan \& Mangematin, 2010).

Numerous works confirm the low salaries of African academics despite budgetary efforts in many countries these recent years. Nevertheless there may exist disparities between sub-regions and countries in Africa on this aspect. This point is noted by most senior fellows for whom the appointment to administrative functions must not only be an opportunity to 
"logically make profitable the investment made in terms of work and research trips to prepare the contest" (Associate Professors and senior fellow, 3 years of experience, UD) but also and mostly to be as well treated financially as their counterparts in West Africa: “...we are the forgotten ones of the system and are almost hopeless.... We have been senior fellow for 6 years now, but even a post of head of office, we do not have, whereas our colleagues in West Africa are directly appointed once they become senior fellow. Furthermore, their salaries in their Universities are three times higher than ours... In our country, the "article 2,"11 is of extreme importance!)(Senior Fellow, 6 years of experience, UYII).

The economic crisis of the 80s (followed by the structural adjustment policy both in Cameroon and in many other African countries) contributed to the deterioration of infrastructural investment, particularly in terms of the working environment of teacher-researchers (Makosso \& al., 2009). It seems that despite many subsequent University reforms, the working conditions of researchers remain tricky. This situation helps to justify the importance that many of surveyed professors attach to the appointment to administrative positions.

This is contrary to certain analyzes that tend to identify in the West a certain repugnance of researchers to bureaucratic or administrative tasks (Courpasson \& Guedri, 2007). The promotion to such positions is thus aimed not only for the prestige or the feeling of "recognition by the nation" but also and mainly because it can allow the Professors concerned to have offices: "...Predecessors who have not been appointed in Universities are rare... many are in ministries, Prime Minister office, at the presidency, etc. ...we are wondering if it is during the retirement that the nation will value our merit....... the height is that in the meantime, my personal car continues to serve as an office to discuss with students about their work (Prof, 3 years of seniority, UYII).

\section{$3.2 \ll$ Job Seeker» Configuration}

Junior researchers and more specifically instructors without $\mathrm{PhD}$ are the main players in this configuration. Their remarks legitimate in somehow the theory that professional insertion is one of the objectives of young researchers in management Sciences (Verstraete, 2007). Hence, they can opt for a career at the University. Thus, $80 \%$ of female PhD students in our sample are considering for various reasons (advanced age, image...), the defense of the doctoral thesis exclusively from a prospect of short-term application for recruitment at the University “...age keeps advancing...It is necessary to find a job to allow parents especially to blow financially...but, personally my childhood dream is to be a professor in the University...It seems like the MINESUP ${ }^{I 2}$ will soon open positions for recruitment in Universities, especially those that have recently been created, it is a godsend to exploit absolutely"(PhD student-instructor, 3rd year thesis, 26 Years).

Nevertheless the holding of a doctorate degree is no longer a guarantee of recruitment in the University or in the firms in Africa (Doucouré, 2014) as was the case in the years 1960-1970. Far from being an African specificity, the situation is due to budgetary austerity consecutive to the structural adjustment constraints of the 1980-1990. Their negative effects on the recruitment of teacher-researchers in local Universities continue to manifest themselves up to a very recent past. It would also be linked to the explosion in the number of doctors trained internally merely by the U. YII and U. D., who orchestrates the competition for recruitment in the Universities.

In this situation, some junior researchers, especially those of the UD, rather consider extra-academic careers (Glick, Miller and Cardinal, 2007) notably in private firms: "I have defended my thesis three years ago and sought in vain to have a position in three universities...I do not lose hope... While waiting, I'm also exploring possibilities in big private enterprises that abound here in Douala...I think the goal is to find a job...otherwise, my doctorate would have been useless $\gg(\mathrm{PhD}$ student-instructor, 3rd year thesis, UD).

\section{3 «Pro-credibility» Configuration}

Since the end of the 1980s, there has been a proliferation of Universities in Africa (Gaillard \& Vaast, 1988). The consequence of this proliferation has been the explosion of the doctors produced who are generally experiencing difficulties of professional integration as the previous developments suggest. Nevertheless, it turns out that the PhD is paradoxically fashionable and is particularly snobby for some workers (both public and private).

This statement is based on the identification of the perception of the diploma considered as a vector of credibility in their professional circles by the number of $\mathrm{PhD}$ students surveyed who are working simultaneously in private or public enterprises: "It is necessary to create the difference with others...Most of them in our environment have at most the

${ }^{11}$ The respondent here refers to an article which is included in most of the decrees and orders appointing to administrative positions and states that "the persons concerned shall be entitled to the benefits of any kind provided by the regulations in force".

${ }^{12}$ Ministry of Higher Education. 
Bachelor or the Master level... With that level, the hierarchy takes you much more seriously ..."(Professional PhD student, UYII, Tax inspector).

Therefore we are in a context where doctoral researches (particularly in the framework of the professional doctorate proposed in recent years in various African Universities) seem more motivated by a concern for credibility or socio-professional reputation (Doucouré, 2014). This observation gives the opportunity to bounce back on the idea, more developed in the media, according to which there is a cult of doctorate and professorship in Cameroon which are considered as vectors of reputation or social legitimacy ${ }^{13}$.

We would like to point out that almost $10 \%$ of A.P of our study help to verify such theory. In fact they evoke the absence in their tribes or villages of origin of AP to explain their decisions to prepare for the aggregation contest: "There was no [senior Fellow] in the village and even almost throughout the division... It's very complimentary in the elite circle... The honors I have been receiving in the village for some time justify that my decision to go for the contest was not wrong" (Associate Professor of CAMES, 3 years ago, U.D.).

\section{4 «Capitalist» Configuration}

In a context characterized by budgetary constraints that weaken the salary level of researchers as it is the case in Africa (Makosso \& al., 2009), the predisposition of the researchers to engage in parallel lucrative activities may be an indicator of the importance they attach to financial gain. Nevertheless, far from being an African specificity, the financial motivations or researchers exist even in developed countries especially in Europe and the United States where money constitutes a yardstick of social success (Enders \& Musselin, 2008).

Our study further identified such motivations among almost $85 \%$ of lecturers and $95 \%$ of AP concerning the UD. They are particularly justified by the despair of researchers concerned to benefit from promotions at the academic level or at the administrative level: "without administrative responsibilities at the University, there is no reason not to get involved in business elsewhere ...At my age, one must be foolish to expect an appointment as Dean or Director in a ministry ... Once I finish teaching my only second year bachelor's degree course, I cannot hesitate to go to my cabinet or to teach somewhere else especially private Universities.»(A.P, U.D., 10 years of experience).

As far as the Lecturers are concerned, the results show that they are also characterized by their strong propensity to change rank at "any cost". In this case, the change of University degree is conceived as a springboard to benefit from the research premiums foreseen for the rank of A.P concerned: “... publishing in classified journals is good, but it's time consuming.... At my age, one can't make it a goal. The retirement is no far...It is necessary to publish anywhere so far as it serves in the short term to send my file to the CCIU for the grade of A.P. ...We must do everything to enjoy it [prime] before going on retirement»(Lecturer, U.YII, 8 years of experience).

The premiums mentioned here are those recently instituted in Cameroon by the presidential decree $\mathrm{N}^{\circ}$. 2009/121 of the $08^{\text {th }}$ of April 2009 creating, organizing and operating a special account for the modernization of research in the State Universities.

\section{5 «Academist» Configuration}

Most young Associate Professors (almost 60\%) and Full Professors (90\%) fall first, certainly with different logics, in this category of researchers characterized by a deep attachment to the values and the scientific career. Scientific requirements are universal and are particularly necessary for researchers in African Universities (Gaillard \& Vaast, 1988). Therefore, it can be understood that scientific performance (in terms of rigorous publications in established scientific journals) falls within the category of peculiar values of some African researchers. This kind of performance may then be preferred to the occupation of administrative functions notably.

The present scenario mainly concerns the above-mentioned A.P. They illustrate themselves more by elitist ambitions at the scientific level (Doucouré, 2014). They share the view that administrative positions, beyond the stress they can generate because of the uncertainty over the duration at the position (which is essentially political), potentially generate a workload that could reduce the scientific productivity. The problem here is that the scientific promotion this scientific productivity in terms of rank: "Being appointed Dean, Vice-dean, etc., is very prestigious...But my appreciation of the situation is that it can be very absorbing in the long run and become dangerous. One can easily forget himself at this post while it is only a political one that can be lost at any moment... One must continue to publish articles. Once acquired, the title of Professor is almost eternal..." (A.P of CAMES, 3 years of experience).

The 1993 University reform in Cameroon (notably the decree No. 93/035 of the $19^{\text {th }}$ of January 1993 on the special status of higher education personnel) established the title of Professor emeritus for full professors at the end of their

\footnotetext{
${ }^{13}$ Reference to internet siteswww.cameroon-info.net and www.camer.be.
} 
career. Scientific performance, as well as other activities such as teaching, fall under the required conditions (Ndjodo \& Onana, 2012).It is likely to generate strategic behavior of candidates ${ }^{14}$.

We have presumed such behavior by observing the obstinacy of some professors to claim the direction of several doctoral theses and to intervene in various lectures at a time, despite the proven proximity of their retirement (set at 65 in Cameroon): "Do not force my departure from the University, I can still teach all my courses ... We must work to ensure that teachers reach the highest rank rather than limiting the recruitment of doctoral students"(Professor, UYII, 2 years to retirement).

\section{Conclusion: managerial implication and limitations of the study}

The concern that research in Management Sciences is used to solve concrete problems has been increasingly important since the end of the year's 1970. Nevertheless, the debate is focused on the utility of this research for firms especially in the context of Western countries. The question of the self-referentiality of research that relates to the researcher's ethos is generally under-explored and even dreaded.

This theory relating to the dehumanization or depersonalization of research is exploited in this study. It is specifically mobilized to explain the crises that some Universities, especially in Africa, face in their research governance. We consider in this study that these crises would persist in spite of reforms undertaken if such reforms do not lead to measures capable of favoring the satisfaction of the personal needs of researchers.

This study has relied more on the representation of research as an activity that is far from impersonal. It therefore considers that the development of good academic governance in research requires the self-centeredness of the researcher to be taken into account. Nevertheless, the personal desires of the latter still escape a precise understanding and therefore constitute an important object of investigation.

The ambition of this article was therefore to contribute to better understanding of the personal motivations, terms inspired by psychologists, of researchers supposing that these are the basis of their commitment at their job. For this project, we mobilize the reading grids specific to sociology or psychology which positions the stakes of personal desires. The conceptualization effort mobilizes also studies carried out in the western context which allow rebound on researcher's careers at the University. The analysis of the results of our empirical investigations in two Cameroonian Universities leads to the fact that the commitment to exercise research activities is motivated by different desires of the researcher.

These researcher's motivations identified have been voluntarily organized into five configurations. The major configurations identified are related to mercantile orientation, the search for administrative power or scientific promotion, the need for social reputation and the desire for professional insertion of researchers. In others words, the needs for financial enrichment and promotions to administrative positions or in terms of academic / scientific grade change characterize certain researchers in their activities. Likewise, the quest for social reputation and the concerns of insertion into the professional world are far from being neutral on the decisions of engagement in the activity of research.

We have shown how these motivations are expressed differently according to the profiles of researchers, particularly in terms of grade, status (Senior/junior), impending retirement and even the geographical location of the University of the Researcher. We would like to observe that, in general, the problems that private or public firms experience are rarely mentioned by our interviewees when they speak of the utility of research activities. The surprising nature of this observation has been noted in view of the fact that the researchers studied belong to a scientific area (the management sciences) where the firm is generally considered as the central object.

In any case, the identified motivations provide important benchmarks from which Universities generally can strengthen or enrich their research-focused policy. It is quite true that they are the result of an experiment confined to researchers in a single scientific field (management sciences) and limited on two universities. Nevertheless, we would like to observe that it would be interesting for local Universities to become aware of and to consider all the desires identified in the context of managing their staff (Gordon \& Whitchurch, 2007).

It seems that the consideration and satisfaction of these desires constitute factors of good University governance for research activity. In terms of managerial implications, the implementation of these factors is the responsibility of the Universities with regard to their autonomy. It's also mostly a State affair due to the influencing power that the State

\footnotetext{
${ }^{14}$ Reference to the article «Des règles pour devenir et demeurer professeur émérite. Polémique à Lyon 3» which is available at www.histoiresduniversité.file.worldpress.com.
} 
permanently undergoes in the structure of University governance ${ }^{15}$. There is therefore a situation of partial University dependence.

It can therefore be assumed that the organizational challenges raised by the desires of financial enrichment and the administrative promotion of researchers in particular, call for more reflection on research policy at the ministerial, interministerial or State level. In this respect, there would be in Cameroon as in many developing or African countries, an interest to deepen the discussions at institutional level on the policy of "fonctionnarisation" of researchers, empowerment and the choice of a functioning model (accommodation versus employer) of Universities, the incentive or pay policy and the division of labor (researcher/teacher).

Debates on the reform of higher education or specifically Universities, seem to be at a more advanced level and are conducted exclusively in developed countries (Enders \& Musselin, 2008).In deeply analyzing these aspects in other works, it would be beneficial to take into account the limitations of this research.

These limitations concern mostly the exploratory character of the study taking into account the weakness of units of analysis or the respondents and the qualitative nature of the method. It concern also the omission of the age of the respondents, the focusing on only two Universities, the lack of and deepen appreciation of the situation of women in particular. We would especially like to observe that the relevance of mobilizing the configuration approach to present our results is debatable. Indeed, the configuration is only a map that proves to be insufficient in identifying all the situations: "the map is not the territory".

\section{References}

Alvarez, F., \& Oriot, F. (2007). L'interaction « chercheur-sujets organisationnels»: du discours au sens. In Martinet A.C. (dir.) Sciences du management Epistémique, pragmatique et éthique (139-165), FNEGE.

Banks, J. C., \& al. (2016). Management's Science-Practice Gap: a Grand Challenge for all Stakeholders, Academy of Management Journal, 59(6), 2205-2255. https://doi.org/10.5465/amj.2015.0728

Barthelemy, G. (2012). Pour une recherche en gestion conciliant rigueur et pertinence. Revue Française de Gestion, 9(228), 269-289. https://doi.org/10.3166/rfg.228-229.269-283

Baumard, P. (2012). Michael Polànyi Connaissance et liberté, In O. Germain \& N. Brunson (dir.), Les grands inspirateurs de la théorie des organisations (pp.294-309), EMS.

Benis, W., \& O’Toole, J. (2005). How Business Schools Lost Their Way, Harvard Business Review, 83(5), 96-104.

Beyer, J. M., \& Trist, H. M. (1982). The utilization Process: a Conceptual Framework and Synthesis of Empirical Findings. Administrative Science Quarterly, 27(4), 591-622. https://doi.org/10.2307/2392533

Charreire, S., \& Huault, I. (2001). Le constructivisme dans la pratique de recherche : une évaluation à partir de seize thèses de doctorat. Revue Finance Contrôle Stratégie, 4(3), 31-55.

Côme, T. (2013). La gouvernance des Universités. Revue Politique et Management Public, 3(2), 1-5. https://doi.org/10.3917/gmp.021.0001

Courpasson, D., \& Guedri, Z. (2007). Les professeurs-Chercheurs en Management face à la performance scientifique. Revue Française de Gestion, 178, 173-194. https://doi.org/10.3166/rfg.178-179.173-194

Dahan, A., \& Mangematin, V. (2010). Recherche ou temps perdu ? Vers une intégration des taches administratives au métier d'enseignant-chercheur. Gérer \& Comprendre, 102, 14-24. https://doi.org/10.3917/geco.102.0014

Damtew, T., \& Heinz, G. (2010). Mondialisation et enseignement supérieur en Afrique . In T. Damtew \& G. Heinz (ed.) Enseignement supérieur et mondialisation : défis, menace et opportunité pour l'Afrique (pp.1-8), Maastrich University.

Demil, B., Lecocq, X., \& Warnier, V. (2014). Qu'est ce qu'une recherche utile ? Revue Internationale PME, 3, 6-13.

Denis, J-P., \& al. (2011). Gouvernance et stratégies des groupes, Lavoisier, Paris.

Deschamps, J. F., \& Finkelstein, R. (2012). Existe-t-il un véritable altruisme basé sur les valeurs personnelles. Cahiers Internationaux de Psychologie Sociale, 37-62. https://doi.org/10.3917/cips.093.0037

Doucouré, B. (2014). L'insertion professionnelle des jeunes docteurs au Sénégal. Hommes \& Migrations, 1307, 87-92.

${ }^{15}$ In Cameroonian Universities, rectors, deans and all administrative directors are appointed by the Head of State. Similarly, administrative staff at the rank of deputy director, including directors of research centers, and chief of service are appointed by the Minister of Higher Education.The powers of the Rector of the University are almost limited to the appointment of the heads of offices and support staff. 
https://doi.org/10.4000/hommesmigrations.2884

Enders, J., \& Musselin, C. (2008). Retour vers le futur ? Les professions universitaires au XXIe siècle. In Enders, J. \& Musselin, C. (Dir.) L'enseignement supérieur à l'horizon 2030, (pp.131-160), OCDE. https://doi.org/10.1787/9789264040687-5-fr

Gaillard, J., \& Gaast, R. (1988). La recherche scientifique en Afrique. Afrique Contemporaine, 148, 2-27.

Gatignol, C. (2014). L'environnement professionnel des enseignants chercheurs français explique-t-il leurs parcours de carrière ?. GRH, 2(11), 51-80. https://doi.org/10.3917/grh.142.0051

Girolamo, R. (2004). Les liens entre le CNRS et l'Université, Revue Française de l'Administration Publique, 4(112), 637-646. https://doi.org/10.3917/rfap.112.0637

Glick, W. H., Miller, C. C., \& Cardinal, L. B. (2007). Making a life in the Field of Organization Sciences, Journal of Organization Behavior, 28, 817-835. https://doi.org/10.1002/job.455

Gordon, G., \& Whitchurch, C. (2007). La gestion des ressources humaines dans l'enseignement supérieur: la diversification des fonctions et ses conséquences. Revue Politiques et Gestion de l'enseignement Supérieur, 19, 151-176. https://doi.org/10.1787/hemp-v19-art14-fr

Houcine, R. (2017). Des mauvaises « reformes » à la « bonne» gouvernance. In Oleg C. \& Mohamed M.(dir), Regards dynamiques et critiques de la bonne gouvernance, ( pp.35-50), IAUPL.

Jaziri, T., \& Levy-Tadjine, T. (2009). Conventions et Acadépreneuriat au cœur de la gouvernance universitaire. Revue Libanaise de Gestion et d'Economie, 2, 1-29. https://doi.org/10.1016/S2214-4234(09)70013-4

Kauffman, J. C. (1999). L'entretien compréhensif. Paris, Nathan.

Kezar, A., \& Eckel, D. E. (2004). Meeting Today's Governance Challenges: A Synthesis of the Literature and Examination of a Future Agenda for Scholarship. The Journal of Higher Education, 4, 371-399. https://doi.org/10.1080/00221546.2004.11772264

Khefacha, I., \& Belkacem, L. (2010). University Governance: Empirical evidence from Tunisian Public Higher Education Establishments. Revue Gouvernance, 7(2), 1-21. https://doi.org/10.7202/1038922ar

Le Goff, J. (2012). Charles Sanders Peirce, fondation du pragmatisme et découverte de l'abduction. In O. Germain (dir.) Les grands auteurs de la théorie des organisations, (pp.275-292), EMS.

Louvel, S., \& Valette, A. (2014). Les carrières à l'Université Une approche par les modes d'engagement dans la promotion. Revue d'Anthropologie des Connaisances, 8(3), 523-546. https://doi.org/10.3917/rac.024.0523

Makosso, B., \& al. (2009). Enseignement supérieur en Afrique francophone Crises, reformes et transformation : Etude comparative entre le Congo, le Cameroun, la Côte d'Ivoire et le Burkina Faso. Rapport Codesria.

Menye, N. (2014). Organisation du travail, stress et conséquences en milieu universitaire. Psychologie du travail et des Organisations, 20(2), 111-132. https://doi.org/10.1016/S1420-2530(16)30034-6

Ndjodo, M. F., \& Onana, C. A. (2012). Les reformes de gouvernance dans l'enseignement supérieur Camerounais, Rapport, Unesco.

Paradas, A. (2012). L'homme comme sujet, Revue Interdisciplinaire Management, Homme(s) \& Entreprise, 2(2), 3-16. https://doi.org/10.3917/rimhe.002.0003

Verstraete, T. (2007). A la recherche des Sciences de Gestion. Revue Française de Gestion, 179, 91-105. https://doi.org/10.3166/rfg.178-179.91-105

\section{Copyrights}

Copyright for this article is retained by the author(s), with first publication rights granted to the journal.

This is an open-access article distributed under the terms and conditions of the Creative Commons Attribution license which permits unrestricted use, distribution, and reproduction in any medium, provided the original work is properly cited. 